\title{
Influence of Time-on-phone on Undergraduates Academic Achievement in Nigerian Universities
}

\author{
Adeleke, Ayobami Gideon* \\ Institute of Education, Obafemi Awolowo University, Ile-Ife, Nigeria \\ *Corresponding author: aygold10@gmail.com
}

\begin{abstract}
The influx of tech-novation influences education and especially learning inestimably. This study looks into the usage and perceived influence of Smartphones by Nigerian undergraduates on the academic performance. It investigates the relationship between time and academic achievement alongside variables that directly and indirectly impact on Smartphones' usage. These were with a view to improving and maintaining academic achievement though tech-novation. Descriptive survey design was adopted. All undergraduate students in Nigerian universities estimated 1,700,000 (UIS, 2012) make the population. 150 undergraduates were randomly sampled from three institutions purposively selected in south-west Nigeria. A structured questionnaire dubbed 'Smartphones and Academic Achievement (SPA)' was used for data collection. Data was analysed descriptively. The results expatiated on the usage of smartphones among Nigerian undergraduates. It reflected that majority users are bereft of any influence of usage on their achievement academically and significant times sub-consciously expended on the phone. It also revealed the disparity between direct and indirect variables that impact on time-on-phone of undergraduates. The result further revealed that high time-on-phone across the variables influences lower academic achievement. The study concluded that the smartphone tech-novation will only add value to education, bridge the gap of access to information and publications, provided it is adequately controlled.
\end{abstract}

Keywords: Smartphone, time-on-phone, tech-novation, usage, undergraduates

Cite This Article: Adeleke, Ayobami Gideon, "Influence of Time-on-phone on Undergraduates Academic Achievement in Nigerian Universities.” American Journal of Educational Research, vol. 5, no. 5 (2017): $564-567$. doi: 10.12691/education-5-5-14.

\section{Introduction}

Students are the key asset of universities [2]. The quality of the output in an education industry significantly determines the worth and ranking of the institution. The product (graduate) becomes leaders, manpower for the country, responsible for the future of their country's economic and social development. Academic achievement is equally considered by employers in hiring fresh graduates thus, students' efforts put into their studies prepare them for future opportunities, career and selffulfillment. Marquez [4] reiterated that a student who is successful in his desired career has a good study habit. Students should apply good study habit into all of their classes hence not attempt multi-tasking and multiple subjects studying in a single period.

The 20th century dawns with information and communication technology (ICT) struggling into the education system. The wake of the 21st century has ICT in its multivariate tech novations not struggling but needful, influential and pragmatically applied in the education industry from preschool, basic school, graduate studies, skill acquisition, adult learning and special needs education. Though the impact is loudly touted in literature [1], a particular trend of distraction is being observed to perhaps reduce the good study habit of learners, hitching on the quality study time and impacting academic performance - the boost of Smartphones.

The smartphones, being a very new invention of humanity, became an inherent part of human's life. The smartphone combines different sophisticated features. Merriam-Webster dictionary defines the smartphone as "a cell phone that includes additional software functions (as e-mail or an Internet browser)". According to Miakotko [3], a smartphone allows users to keep pictures, memories, personal info, correspondence, health and financial data in one place. Smartphones also became an integral part of modern telecommunications facilities. The phones allow people to maintain continuous communication without interruption of their movements and distances. Smartphones and handheld devices (HHD) combine advanced computing capability, such as internet communication, information retrieval, video, e-commerce and other features, that make the device as one of the necessities for many people [3]. MidYork Library System (2012) highlighted the uniqueness of Smartphone over a Telephone and Cellular Telephone in a comparison [Figure 1].

Researchers found that cell phone technology invaded humanity probably some ten or fifteen years ago. According to GSMA Intelligence cited in Miakotko [3], the number of mobile devices is 7.22 billion while the US Census Bureau says this figure is still between 7.19 and 7.2 billion. The statistic of users in Nigeria is unavailable, growing number of smartphones and smartphone ownership 
is overt among the school-age population. The concern thus raised is about Smartphone's usage and its effect on educational performances. The author implies that the handheld devices (HHDs) that have multivariate features in the hands of young, easily addictive people who often become anxious or stressed out when they do not have access to the device, easily distracted them away from their lessons at school.

In accordance with Goundar [6], educators are discovering that students are more interested in online resources, such as Facebook, game sites, chat, and YouTube than classroom lectures and textbook chapters. The impact of this on learning outcome in terms of grades of the students must not be left to guess. Hence, this study investigated the relationship between time-on-phone and academic performances. It also peered into factors, directly and indirectly, calling for the usage of tablets, smartphones, netbooks, and suchlike distractive qualities of technology in schools by the learners.

The study adopted the Technological Pedagogic Content Knowledge (TPCK) of Mishra \& Koehler (2006) and Koehler \& Mishra (2009) as the theoretical framework. TPCK favours the use of technology in teaching. This implies that when stakeholders appreciate the role of ICT in teaching, adopting or adapting it as a necessary tool, learning is made easy. TPCK built on Shulman (1986) process content knowledge concept. It emphasises the intersection among technology, content and pedagogical knowledge and links technology, pedagogy and content knowledge so that technology may be integrated into the teaching-learning process. Thus, TPCK involves teachers and students knowing when, where and how to use ICT which may include the use of the internet, smartphones and other HHDs. Imperatively, Africa is terribly limited in internet usage despite its multivariate benefits and impactful usage in education. There are 345,676,501 of 1,246,504,865 estimated internet users in Africa with a $27.7 \%$ penetration and only $9.3 \%$ of total world users. Nigeria's estimated population of 191,835,936 in March, 2017 has internet users of $91,880,032$; a $47.9 \%$ of the population and $8.3 \%$ penetration rate [7]. This suggests the much less widespread use of ICT in developing nations of the world compare to the developed. Considering this low penetration rate of internet using computers, smartphones might provide the cheapest and quickest access to the Internet for the majority of Nigerian dwellers.

\section{Methodology}

Research Design - a quantitative type of research was used in this study. The researcher used the descriptive survey method in the conduct of the study.

Locale of the Study - The study was conducted in Osun State, south-west Nigeria.

Respondents of the Study - Respondents were from three representative universities in Osun, Nigeria. 150 undergraduates from each of the private, state and federal university stratified into the study were sampled.

Instrumentation - Total enumeration sampling was used. Self-reporting questionnaire was used to gather data on Smartphones and academic performance of undergraduates. The instrument was trial-tested for reliability on twenty undergraduates in another state. The result instilled confidence for use with 0.71 Cronbach Alpha coefficient value.

Data Gathering Procedure - Ethical consideration was referenced by seeking the consent of universities management. The respondents, though adults were willing volunteers. Questionnaires were distributed to the respondents after thorough explanation. A request for cooperation was solicited and assurance of anonymity given. Two research assistants aided the data collection process.

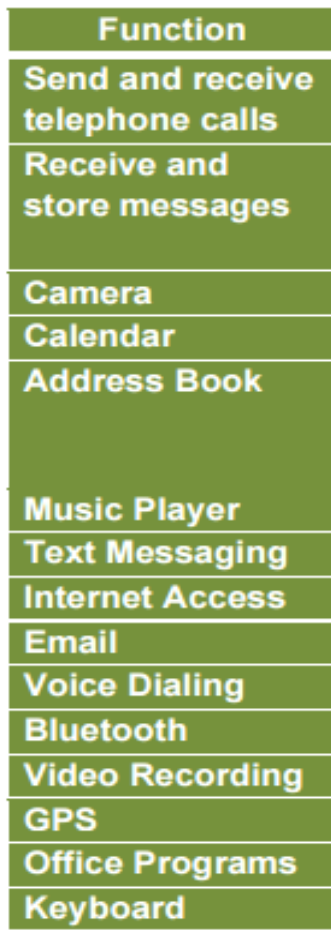

\begin{tabular}{|l|}
\hline \multicolumn{1}{|c|}{ Telephone } \\
Yes \\
Yes, with answering \\
machine attached or \\
built in \\
\hline No \\
\hline No \\
Some, but usually only \\
names and telephone \\
numbers \\
\hline No \\
\hline No \\
No \\
\hline No \\
No \\
No \\
\hline No \\
No \\
\hline No \\
No
\end{tabular}

\begin{tabular}{|l|l|}
\hline \multicolumn{1}{|c|}{ Cellphone } & \multicolumn{2}{|c|}{ Smartphone } \\
\hline Yes & Yes \\
\hline Yes & Yes \\
& \\
& \\
\hline Some & Yes \\
\hline Some, but limited & Yes \\
\hline Yes & Yes \\
& \\
\hline No & Yes \\
\hline Some & Yes \\
\hline Some & Yes \\
\hline Some & Yes \\
\hline Some & Yes \\
\hline Some & Yes \\
\hline Some & Yes \\
\hline Some & Yes \\
\hline No & Yes \\
\hline Some & Yes \\
\hline
\end{tabular}

Figure 1. Comparison of features between a Telephone, Cellular Telephone and Smartphone (MidYork Library System, 2012) 


\section{Results and Discussions}

The initial objective of the study is to establish the relationship between time spent on the phone and academic performance of Nigerian undergraduates. The result of analyzed data indicated positive and significant relationship (Table 1). The correlation coefficient of 0.398 , $\mathrm{p}<0.05$ signalled that time spent on phone affects academic performance.

In the view of Langmia and Glass [9], teaching faculty members could use smartphones for pedagogic reasons and experience positive results. Strict classroom phone policy might be applied with little success. Louis-Philippe and Richard [8] in a survey found mobile phone steady increase in ownership reaching 94\% in 2011 among students in England. The impact on student test scores finds that student performance in high stakes exams significantly increases post ban. They concluded that restricting mobile phone use can be a low-cost policy to reduce educational inequalities. These previous but recent researches require discernment and tact in engaging students with a smartphone and exclusively for academic purposes especially in the school environment. If time spent on the phone has a direct and significant relationship on academic performance as found in this study, Nigerian undergraduates must be properly guided in view of the dire and needful situations they find themselves. This is further investigated in succeeding study objective.

Investigation was also carried out on variables that necessitate the usage of smartphones among undergraduates with a view to reviewing their strength of influence. The study found that the direct and indirect variables are all significant and influential (Table 2). Important among such indirect variables were: the institutions lack adequate computers, reducing the cost of phones, incessant power failure, pressure to hold modern phones among others while direct variables include the availability of learning programmes online, practical utility in smartphones functions, smartphones in education space and such likes.

Table 2 depicts that these variables - direct and indirect - responsibly necessitate the usage of smartphones among undergraduates. The strength of influence of the variables is shown in $F$ ratio from the statistical table for significance. There is the significant influence of variables (direct and indirect) on time-on-phone $\left(F_{(9,140)}=7.258, \mathrm{p}<0.05\right)$. Clayton and Murphy (2016) saw Smartphones as regular classroom accessories necessary for educators to work with children for learning and civic engagement, rather than being a classroom distraction.

Their research supports a collaborative project the authors engaged in with students to discover what the perception of smartphone use was by students and teachers.

Other findings also showed necessity by results. For example, "student achievement will increase significantly since time-on-task increases significantly when students use MLDs such as smartphones inside the classroom for curricular purposes.” These were the conclusion of Norris, Hossain and Soloway [11]. The authors predicted that every child, within five years in $\mathrm{K}-12$ classrooms in America will be using a mobile learning device having seen a corollary already in use. They added that students' achievement will increase significantly since time-on-task increases significantly when students use mobile learning devices inside the classroom for curricular purposes. The author's predictions were backed up with provocative evidence. They concluded that the medium - the MLDs do matter very much in learning.

To this end, smartphones might be judiciously used by teachers in creating and engaging in effective learning activities, enabling learners to engage in a broad range of interactive learning activities and enact the lessons provided by the teacher.

\section{Conclusion}

This study expatiated on the usage of smartphones among Nigerian undergraduates. Findings showed users are unconscious of impact on their academic performances and quality time. It as well revealed the polarity between direct and indirect variables necessitating smartphone usage and impact on time-on-phone of undergraduates. Despite investigation confirming that high time-on-phone across the variables result in lower academic achievement, the study concludes that the smartphone tech-novation will add value to education provided it is adapted for curricular purposes and tolerably supervised. Smartphones will ideally bridge the gap of access to information and publications in Nigerian situation but must be adequately controlled and judiciously utilised by teachers in creating and engaging in effective learning activities enabling learners to engage in a broad range of interactive learning activities and enact the lessons provided.

Table 1. Relationship between Time-on-phone and Academic Performance

\begin{tabular}{|l|c|c|c|c|c|}
\hline Group & $\mathbf{N}$ & Mean $\overline{\mathbf{x}}$ & Standard Deviation & r & Sig. (2-tailed) \\
\cline { 1 - 4 } Academic Performance & 150 & 8.5932 & 1.91110 & \multirow{2}{*}{.398} & $.000(\mathrm{p}<0.05)$ \\
\cline { 1 - 5 } Usage of Smart Phones & 150 & 9.6934 & 2.27016 & & \\
\hline
\end{tabular}

Table 2. ANOVA of Variable Impact on Phone Usage

\begin{tabular}{|c|c|c|c|c|c|}
\hline Sources of variation & Degree of freedom (df) & Sum of Squares & Mean Sum of Square (MSS) & F-Ratio (F) & Sig. \\
\hline Between Groups & 9 & 1451.594 & 7265.797 & 7.258 & $.000(p=0.05)$ \\
\hline Within Groups & 140 & 20020.232 & \multirow{2}{*}{1001.012} & & \\
\hline Total & 149 & 34551.826 & & & \\
\hline
\end{tabular}




\section{References}

[1] Adeleke, A. G. (2010). Comparative Effectiveness of Two ICTIntegrated Learning Strategies on Mastery of Numeracy among Lower Primary School Pupils in Ile-Ife, Nigeria. A Master of Art in Early Childhood Education Thesis submitted to the Institute of Education, Obafemi Awolowo University, Ile-Ife, Nigeria.

[2] Alos, S. B., Caranto, L. C.and David, J. J. T. (2015). Factors Affecting the Academic Performance of the Student Nurses of Benguet State University, La Trinidad, Benguet, Philippines. International Journal of Nursing Science 2015, 5(2): 60-65.

[3] Miakotko, L. (2017). The impact of smartphones and mobile devices on human health and life. Retrieved from http://www.nyu.edu/classes/keefer/waoe/miakotkol.pdf

[4] Marquez, M. S. (2009). Ways of Encouragement for Successful Study Habits. Modern Teacher, p. 13.

[5] Samantha F. (2016). Smartphones In Classrooms: Is It Damaging Or Improving Children's Education? Parent Herald. Retrieved at https://www.smu.edu.sg/sites/default/files/smu/news_room/smu_i n_the_news/2016/Aug2016/Aug26/ParentHerald_20160824_1.pdf.

[6] Goundar, S. (2014). The Distraction of Technology in the
Classroom. Journal of Education \& Human Development. Vol. 3, No. 1, pp. 211-229.

[7] Internetworldstats.com (2017). Internet Usage Statistics for Africa: Africa Internet Usage and March 2017 Population Stats. Miniwatts Marketing Group. Available at http://www.internetworldstats.com/africa.htm.

[8] Louis-Philippe, B. \& Richard, M.(2015). CEP Discussion Paper No 1350: Ill Communication: Technology, Distraction \& Student Performance. Centre's Education and Skills Programme. Economic and Social Research Council. Published by Centre for Economic Performance.

[9] Langmia, K. \& Glass, A. (2014). Coping with Smart Phone 'Distractions' in a College Classroom. Teaching Journalism and Mass Communication, Vol. 4, no. 1, pp. 13-23.

[10] Clayton, K. \& Murphy, A. (2016). Voices from the Field: Smartphone Apps in Education: Students Create Videos to Teach Smartphone Use as Tool for Learning. Journal of Media Literacy Education (2016) 8 (2), 99-109.

[11] Norris, C., Hossain, A. \& Soloway, E. (2011). Using Smartphones as Essential Tools for Learning - A Call to Place Schools on the Right Side of the 21st Century. EDUCATIONAL TECHNOLOGY/May-June. 